\title{
Nursing in the home palliative care: the view of a family member of a patient with cancer*
}

\author{
A enfermagem no cuidado paliativo domiciliar: o olhar do familiar do doente com câncer \\ La enfermería en la atención paliativa domiciliaria: la mirada del familiar del enfermo con \\ cáncer
}

Aline Lima Ribeiro ${ }^{1}$, Carla Simone Leite de Almeida ${ }^{1}$, Kesley de Oliveira Reticena ${ }^{1}$, Maria Rita Guimarães Maia ${ }^{1}$, Catarina Aparecida Sales ${ }^{1}$

This study aimed to understand the concepts of family members of patients with cancer, who were inserted and guided by the actions of an extension project aimed at patients with cancer and their families, about the home care given to them, during the treatment phase and progression of the disease. This is an evaluative qualitative research conducted with six family members from June to October, 2013, through semi-structured interviews, analyzed by the method of content analysis. Three categories emerged: the support of nurses in coping with the disease, creating a bond with the patients and their families and nursing as a link to social support networks. It was understood that the health monitoring in the home context gave to the families and patients support and safety to handle concerns that cancer brought into their lives.

Descriptors: Palliative Care; Medical Oncology; Home Visit; Nursing.

Este estudo buscou compreender as concepções de familiares de pacientes oncológicos, inseridos e acompanhados por ações de um Projeto de Extensão ao doente com câncer e sua família, sobre o acompanhamento domiciliar a eles realizado, durante a fase de tratamento e evolução da doença. Pesquisa qualitativa avaliativa, realizada com seis familiares, no transcorrer de junho-outubro de 2013, por meio de entrevista semiestruturada, analisada pelo método de análise de conteúdo. Emergiram três categorias: o apoio do enfermeiro no enfrentamento da doença; criando vínculo com o paciente e sua família; e a enfermagem como elo às redes sociais de apoio. Compreendeu-se que o acompanhamento em saúde no contexto domiciliar emanou à família e paciente apoio e segurança para lidar com as preocupações que o câncer proporcionou em suas vidas.

Descritores: Cuidados Paliativos; Oncologia; Visita Domiciliar; Enfermagem.

Este estudio buscó comprender las concepciones de familiares de pacientes oncológicos, inseridos y acompañados por acciones de un Proyecto de Extensión al enfermo con cáncer y su familia, acerca del acompañamiento domiciliario a ellos realizado, durante la fase de tratamiento y evolución de la enfermedad. Investigación cualitativa evaluativa, llevada a cabo a través de entrevista semiestructurada con seis familiares entre junio-octubre de 2013, y analizada por el método de análisis de contenido. Emergieron tres categorías: el apoyo del enfermero en el enfrentamiento de la enfermedad; creando vínculo con el paciente y su familia; y la enfermería como ligación a las redes sociales de apoyo. Se entiende que el acompañamiento en salud en el contexto hospitalario posibilitó a la familia y al paciente apoyo y seguridad para lidiar con los daños del cáncer en sus vidas.

Descriptores: Cuidados Paliativos; Oncología Médica; Visita Domiciliaria; Enfermería.

\footnotetext{
*Article originated from the extension project "Palliative care to patients with cancer and their families". Universidade Estadual de Maringá, 2004-2014.

${ }^{1}$ Universidade Estadual de Maringá, Maringá, PR, Brazil.

Corresponding author: Catarina Aparecida Sales

Rua Bragança, 287 apto. 42, zona 7 - CEP: 87020-220 - Maringá, PR, Brazil. E-mail: catasales@hotmail.com
} 


\section{Introduction}

Cancer is currently considered one of the most serious diseases that can affect humans and is related to the possibility of imminent death. Even with technoscientific advances that provide prevention, early detection and treatment for many types of cancer, the disease's stigma is still strong and reinforced by high mortality ${ }^{(1)}$.

The existence of a neoplastic disease in a family member causes great impact on the daily life and the dynamics of a nuclear family, imposing the need for restructuring in order to meet the patient's demands and needs. Regardless of the type of treatment that is done, the presence of the family together with the patient allows him not to feel alone or helpless, helping him not to lose his dignity as a human being ${ }^{(2)}$.

As the disease progresses and death approaches, strategies are used by the family members in order to cope with the difficulties experienced and that will come, permeated by a mixture of feelings and behaviors that need to be understood and followed in the family environment by health professionals ${ }^{(3)}$. In this context, the attention given to the emotional and social support for both the patient and his family is paramount, so that they can face this process with more peace and dignity ${ }^{(4)}$, not facing death as a disastrous fact.

This is the moment when palliative care should be inserted, which has as one of its goals to ensure the best quality of life possible for patients and their families throughout the treatment period and the process of dying and bereavement. To do so, such assistance involves not only the patient's welfare, but the family's comfort, as both require emotional, social and spiritual care, so that care is implemented in a holistic way ${ }^{(1,5)}$.

The palliative approach aims to promote quality of life to the chronic patient without therapeutic possibilities, through relief of his pain and his biological, psychological and spiritual suffering ${ }^{(6)}$. It is a humanized therapy, used since the diagnosis of a chronic degenerative disease like cancer, which assumes greater magnitude in patients whose disease does not respond to curative treatment, especially when it is in its advanced and progressive stage. Thus, it is a duty of health teams to attend patients and their families, since they are directly involved in their treatment process and are present in their terminal phase of life ${ }^{(3,7)}$.

Health professionals can develop palliative care to patients with cancer and their families in different contexts, like in general health institutions in which the patient is hospitalized, in a specific unit within the health institution dedicated exclusively for this purpose, at home and in social institutions that receive cancer patients to undergo anticancer treatment ${ }^{(8)}$.

Among all the kinds of treatments, the home care allows to take care of the person's disease in the own environment where he lives. This is a scenario where professionals can respect the autonomy of the patient/family, develop a comprehensive care and prepare them for death at home, thus providing the possibility of the patient to be close to his loved ones, personal property and present in the context in which he is inserted ${ }^{(9)}$.

In home care, the triad patient, family and multidisciplinary team is an issue that deserves to be highlighted, as the family becomes the core of the educational activities, the patient becomes the focus of attention and surveillance and the health team becomes the base of support to the needs that emerge with the disease's progression ${ }^{(9)}$.

Nursing as an integral member of the palliative multidisciplinary team in a home care service, can act both technically and in the understanding of human nature, directing attention to the holistic needs of the patient and his family, planning and implementing actions that allow the individual to have maximum control over his life and disease ${ }^{(10)}$.

Currently, there is a shortage of public services of home palliative care, or, when they exist, they are punctual, with small and fragmented coverage, besides the lack of preparation of the professionals 
involved. Meanwhile, considering the relevance of this type of palliative care and seeking to highlight the role of nursing in this context, one has as a research question: "How do the relatives of cancer patients who were followed by an extension project of palliative care in their homes perceive the role of nursing in this modality of care?"

Thus, this study had as its objective to understand the conceptions of family members of cancer patients inserted and accompanied by the extension project palliative care to patients with cancer and their families, about the home care given to them during the treatment phase and the disease's progression.

\section{Method}

This is an evaluative research with qualitative approach, because it can be understood as the application of procedures to make judgments about the actions of intervention. The qualitative study aims to understand and explain the dynamics of social relations, which are depositories of beliefs, values, attitudes and habits. It works with the experience, the everyday life and the understanding of the structures and institutions, as a result of targeted human actions. Thus, the reality trimmed by a qualitative research, due to its constant transformation, is richer than the researcher's look can grasp ${ }^{(11)}$.

It was held in a town located in the northwestern region of Paraná, with family members of patients enrolled in the extension project palliative care to patients with cancer and their families, developed by students of the undergraduate and graduate nursing courses at the State University of Maringá, in partnership with the Rede Feminina de Combate ao Cancer [Women's Network Against Cancer], Secretaria de Saúde do Município [Health Department of the City], linked to the Núcleo de Pesquisa, Apoio e Assistência à Família [Center of Research, Support and Assistance to the family] of the university mentioned.

The project supports its actions on ethical, philosophical and charitable assumptions of palliative care and seeks to provide quality of life and minimize suffering to the patients and their families. Through weekly home visits, it is proposed to meet their objective and subjective needs, providing a support system to help them establish a daily routine of life in an active and creative way, empowering them to cope with the disease and proximity of death.

Subjects who had family ties with the patient in the final stages of life and who were accompanied by palliative actions of the extension project were included in the study; who were present in the home visits; with ages over 18 years old and who resided in the city of Maringá-Paraná. The exclusion criterion was the inability to communicate verbally to participate in the interview-survey.

To obtain the participation of subjects, a survey was initially conducted about patients who were followed by the extension project between the years 2010 and 2012. The three-year period was chosen due to the ease of contact and time of the family member with the experience. 54 cases were accompanied. Later on, the subjects were contacted by phone to explain the purpose of the study and after their acceptance the interview was scheduled at their houses.

The steps taken to select subjects did not prioritize quantification, since the qualitative research seeks to base the situations experienced through the understanding of human reality that generates senses and meanings. In this approach, the number of respondents has no relevance, but their experiences in relation to the phenomenon under investigation ${ }^{(11)}$. Thus, subjects were interviewed until the moment when the goal of the study was achieved and the responses started to saturate, making a total of six interviews.

The six interviews, open and recorded, occurred in the subjects' homes, between June and October 2013 and were guided by the question: "How was the assistance given by the student of the extension project to your loved one in your opinion?" A semi-structured interview was also used, with 
sociodemographic questions and notes were taken in a field diary of the non-verbal language expressed by the interviewees.

For the data treatment, the content analysis was adopted. This technique of methodological assessment allows the understanding of content which is explicit and hidden in the recordings that were reduced to texts, through the organization of the data into categories. To do so, some steps were fulfilled, namely: in the first, which corresponds to the pre-analytical phase, there was a superficial reading of the six interviews that composed the corpus and the inventory, ie, the clipping of the speeches through register unit and context. Subsequently, in the second phase, there was the analysis of the material, where the speeches were read exhaustively and repeatedly, in order to establish the important issues and build the empirical categories of the study. Finally, in the third phase, the processing of data and its interpretation was made, which was related to other studies about the subject of the research ${ }^{(11)}$.

From this exercise of organization of significant assertions, the following distribution of statements into thematic categories was conducted: 1) the support of nurses in coping with the disease; 2) creating bonds with the patient and his family and; 3 ) the social support networks.

In relation to ethical issues, as it involves human beings, the project was approved by the Ethics Committee of the State University of Maringá under Opinion No 435/2011. To ensure anonymity, the respondents were randomly called with the name of warm colors, because they convey a sense of warmth, cuddling, coziness and welcoming. Remembering that the word palliative is derived from the Latin word pallium, meaning "cloak", conveying the same warm feeling that warm colors convey ${ }^{(12)}$.

\section{Results}

The six family members interviewed were females, aged from 40 to 67 years old (average 57 years old), and were the patients' primary caregivers. Out of theses, five were spouses of the patient and one was a daughter. Regarding education, five had one to eight years of schooling and one had higher education.

The follow-up period of subjects varied from two to eighteen months, with an average of 11 months of follow-up.

\section{Nurses' support to cope with the disease}

This category was divided into two subcategories: teaching the family member about the patient's physical care and psychological support from the nurse to the patient and his caregiver.

In the first subcategory, teaching the family member about the patient's physical care, the data show that the assistance provided during the weekly home visits carried out by a nurse (student of a postgraduate nursing course) and by undergraduate nursing students, made possible knowledge and the conduction of guidelines and techniques required to minimize the sufferings imposed by the disease to the family and to the patient. She (the nurse) explained how it was done, the question of the medication, tube feeding, to check if, at times, he was vomiting because he was being given too much food. So she explained that, when that happened, we should open the probe, leave it out, to see if he had not done digesting. She spoke, taught a lot of things, so for us it was very good (Red). Ah, she helped me a lot. Wow, she guided me well. There were some things I did and she (the nurse) said 'look, do like this, because it is better even for you' She measured his pressure (patient), checked his temperature, taught me how to do massage, especially on his foot and his hand, she taught me and helped me with everything. She helped me to turn him around, she helped with these things. He didn't have wounds in his back, they taught me to never leave him in the same position so I always turned him around (Orange). I felt very secure in that sense, because whenever I needed, I could call her (nurse from the project), 'what can I do? He (the patient) has diarrhea, has this, has that, and she told me immediately "do this, do that" (Lilac).

The second sub-category, psychological support from nurses to the patient and his caregiver, reveals that the nursing professional's performance, in 
addition to meeting the physical needs of the patient, represented the psychological support that he and his family demanded, providing comfort and safety. oh, for me it was great because due to his situation (the patient), I got very weak, no one expects that. It helped me very much in his care, and in my personal, psychological care too. She talked a lot, she was very sweet and helped a lot, helped him so lovingly, so carefully, you have no idea. Before his coma, she had been following him, gave him very special care, made the dressing, talking to him and soon after, she also talked to me, spent a lot of time talking to me, because she knew I was very sad. It was wonderful, it helped me 100\%, so if I didn't have her support, I'll tell you, of course God comes first, but if I didn't have her support I would suffer much more, because she helped me very much, psychologically (Yellow). They talked about the disease, about other subjects, the hours passed, it seems that this gave him strength (the patient) and for us too. Because it is difficult, it is not easy. From the moment you get the diagnosis, cancer, and you know that cancer has no... as the doctor says, no chances for a cure... It's hard, so it was very important, yes, the psychological support was the strength for us to continue to fight, because it is a struggle that we start, so it was very important, yes it was (Pink). And she is like a psychologist, you know; When she arrived, he opened himself, he told her everything, it seemed that he was unloading. And then she helped him in every way, because she was like a psychologist and had knowledge about the medication and about everything, everything, everything he needed. I think the biggest profit was both on the part of nursing and in psychology, she was everything, you know (Lilac).

\section{Creating a bond with the patient and his family}

By providing a holistic nursing care to patients affected by the disease, the participants were able to mitigate the barriers imposed by the experience of being sick at home, getting closer to the patient and to his family and establishing a bond of trust, respect and solidarity, according to the respondents' reports. She (the nurse of the project) helped and acted like a mother, you know? (smile). It was awesome, wow... I just have to thank her. I think it was due to the bond of friendship that we created. Because, besides coming to teach everything we needed, she also talked as a friend. So we created a friendship, we did not wait for a professional, it was a friend, he (patient) felt that she used to speak as a friend, it was very, very nice, wow, it was a project that, for us, made a difference, very, very much (Lilac). She (nurse) told us and taught us quite a lot, so for us, I thought it was very good and then she became a friend, a friends of ours; then we had my nephew's birthday party, my sister's son, and she came you know, she was a very nice and good girl, very nice, she really helped (Red).

The participants of the extension project demonstrated safety, interest, empathy and responsibility towards the patients and their families, providing joy and moments of relaxation. To do this, they used strategies inherent in their training, whether it is personal, family or professional, according to the speeches of some participants in the following sentences. It was good, I liked the way they were accompanied (refers to her husband and the neighbor who was accompanied by members of the Project). They (students of the project) came here and talked, then they spent time together, for them it was very important and it was nice for me too, because it distracted their heads, they chatted. There were moments when he was very angry, and they (students of the project) came and it was a joyful moment. They chatted, played and changed the subject, and he (patient) told stories ... It was very good (Rose). He was sent by God, an angel, because not everybody has that love, you know? He had already suffered so much, he was so weak. But when she arrived, it was like an injection of strength for us (Yellow). She (the student of the project) cheered him up, you know? The days she did not come the other two girls came and it was the same thing, they were cheerful, they came and brought happiness, you know? It was very good, very, very good (Lilac). They (students of the project) came here and he (the patient) was really bad. They brought a canary for him, which they had always promised to bring, wow, he was so pleased with the little canary (Purple).

Patients and their families could find in nursing support and empathy that, in many moments, they did not identify in other professionals or services available in the health care network. Ah... (sigh) he loved her (nurse) and he could not stand the psychologist (laughter), because the psychologist used to ask questions, pushing a situation, which I guess she shouldn't, because she wanted to know what we would do after his death, which are issues that sometimes we did not want to talk about, I never talked about this subject with her and she (psychologist) tried a lot to talk about that (Lilac). 


\section{Social support networks}

This category was divided into two subcategories: nursing as a link to support networks and inefficiency of support networks.

The first subcategory, nursing as a link to support networks, states that when they enter the context of the disease, the family members needed help to solve social and financial problems imposed by it. In that moment, the support networks available are wanted and used as a framework. The female network was a support that helped me financially, with food, diet, they gave basic food, medicine. But people from the church and friends were the ones who helped more, especially with money, because they had to buy food and medicine. There are a lot of expenses, a lot of things that you have to buy (Red).

Even when they are available in the community, the population is usually not aware of the support networks. Meanwhile, the monitoring developed in the actions of the project raised the patient-family dyad, a link with these available networks, providing access, enrollment, benefit and monitoring. They (students of the project) made his registration, everything correctly, so that I could get his milk... (Orange). They were wonderful in everything. They provided a physical therapist because I went to the health unit and was unable to get one, even in the situation he was in, I couldn't. They went to the health unit and arranged a nurse to come every day to make the dressing, give medication, a psychologist who came every Wednesdays and Fridays, and a doctor who visited him. In the cancer institution (female network for fighting cancer), they (students of the project) helped me make my husband's record. From there came the food, diapers and diet probe... Even the oxygen he needed and used for three months, they were able to get, otherwise we would have to buy the device and everything else (Yellow).

The second subcategory, the inefficiency of support networks, points to some impasses between the patient and his family and the social support networks. Even after being established by the project, the access and registration of the patient and his family to the social networks available in the community, due to bureaucratic problems, inherent in the processes of these networks, there was waiting time. Unfortunately, this time was not compatible with the time cancer gives to the patient, making the beneficiary not able to receive his financial help. These things are so slow that when they finally come, the person no longer exists. Very slow, wow, people don't have that flexibility of helping another person quickly. I did everything I could to get that milk. Can you believe that when it finally came, he was no longer alive (laughter, with expression of being dissatisfied) then, there were lots of milk cartons I had to give to others in need. It was not easy my dear, one fights so much that not even this financial support, he had a dream of receiving, the following week after he died, a little paper came here with a message to receive the financial support, I asked the lawyer if I could get it, but he said I would have to try it again, then I tried and I am still waiting for an answer, you can imagine how these things are. They're difficult! (Orange).

\section{Discussion}

Historically and culturally, among all the roles played by women, the caregiver is the most evident in the context of a disease. On issues related to a sick family member's care, be it a spouse, child or parent, the woman is implicitly associated as the primary caregivers $^{(13)}$. This is verified by this study, since all women interviewed were caregivers of a spouse or a father with cancer.

As primary caregivers, women received the guidance of nurses, professionals who were prepared to recognize the signs and symptoms and intervene early to prevent, promote and ensure quality of life for individuals who experience this period ${ }^{(5)}$. It can be seen from the reports of the patient's family members, that such actions were held by nurses and students in their visits and even by phone when necessary.

Besides controlling the physical symptoms in the human terminal phase, mainly because cancer has a prominent social stigma, it is essential to recognize the psychosocial, emotional and spiritual demands that emerge with the disease ${ }^{(14)}$. In this sense, it stands out in the interviewees' speeches, that such demands were met in every visit, making them feel supported and safe. 
From this perspective, a home visit is one of the most valuable tools that nurses can develop because in that caregiving context, it is possible to identify the needs of patients and their families, as well as knowing the reality and the factors that may contribute to their treatment and care process ${ }^{(15)}$. Thus, it is noteworthy that, in nursing, palliative care can be offered through living and sharing of moments of love and passion, therapeutically, showing that death is a natural process and providing the patient and his family support and acceptance ${ }^{(5)}$.

Nurses seek to ameliorate the difficulties experienced during the illness and the fact of being sick, once the anguish and the unpreparedness to deal with such situation can lead to social, psychological and physical chaos, and extenuate their energies to face this painful process ${ }^{(16)}$. In this sense, it became clear that the family considered the performance of palliative nursing home care essential to their sick loved ones, as they felt supported and strengthened to cope with the illness and its consequences.

Realizing the importance of their presence in a home affected by this vicissitude, nurses have built a trusting relationship with patients and their families, since the continuity of home visits, the concern and the follow-up of the family unit allowed the establishment of a connection that goes beyond the entry of "outsiders" in their houses' routine, using important attributes learned in their humanistic education as genuine, compassionate, thoughtful, honest and creative human beings ${ }^{(17)}$.

To do so, in cases when the therapy does not bring healing, holistic care that addresses all the needs of the patient and his family, demands the involvement of a multidisciplinary team, formed by physicians, social workers, psychologists, physiotherapists, occupational therapists, pharmacists, dietitians, chaplains, dentists and speech therapists, in addition to nurses ${ }^{(12)}$.

Care developed by extension actions is affected only by the nursing staff, impeding one to offer palliative care in a multidisciplinary way. Therefore, when one identifies a need for support that goes beyond the capacity of nursing and encompasses actions of other professionals, nurses seek to supply them with the support of social networks available in the community. A Social Support Network is made up by people, structures and institutions that accompany the individual throughout life. In them, the patient keeps a social bond, which involves material assistance, and emotional sense of belonging to the context in which he is inserted ${ }^{(18)}$. Therefore, social support networks are very important, since they offer the family and the patient support to overcome the challenges inherent to the disease ${ }^{(19-20)}$.

The weekly nursing follow-up, offered by the extension action, recognizes the material, social and emotional needs of the patient and his family, establishing a link with the social support networks available in the community and by intervening in the trajectory of search for care directs people in the paths that lead to the resolution of their needs.

The fact that the social networking is inserted into the community does not guarantee, however, that the patient and his family will have access and support, as shown by the interviewees in this study. They were unaware of the available networks, pointing difficulties in establishing links with them as well as dissatisfaction with the organization of the service offered. Faced with such difficulties, as a mediator, the project was important in addressing and meeting the needs imposed by the disease, as well as in the terminally ill patient's life.

Thus, it is verified that when nursing is present in the experience of illness and end of life due to cancer, it plans and implements actions that will allow to patients and their families as much control over their life and disease as possible, leading them to face the process with more tranquility, dignity and autonomy ${ }^{(4,21)}$. 


\section{Final Considerations}

The female relatives of cancer patients in palliative care showed they were satisfied with the follow-up care developed by the nurses of the extension project and demonstrated in their speeches their importance during the disease.

The home care developed by the nursing staff enabled interventions with the essence of palliative care, helping with the patients' physical needs through guidelines and the implementation of procedures, offering a differentiated attention to the families accompanied and establishing ties with them. Based on it, the binomial patient-family felt safe and supported during the process of treatment and at the time of death and mourning, since the approach and the connection with the professional gave them a better quality of life.

The study allowed the understanding of the cancer events in the life of the patient and his family and the importance of nursing care in the experience of illness and end of life. The need of support from the social networks was evident in the context of getting ill, as well as their low effectiveness, showing the necessity of the mediators' actions.

As a weak point, one points the reduced number of people accompanied by this kind of attention in the study site and, consequently, the results cannot be generalized.

By understanding the importance of palliative nursing home care, professionals raise their awareness about the importance of actions taken on behalf of cancer patients and their families. It calls the attention of managers to the need for expansion of palliative care in health care and that the professionals involved in the care process act as mediators together with the social support networks, facilitating the users' access through resolving actions and integrated health services.

\section{Collaborations}

Ribeiro AL contributed to the design of the study, data collection, analysis and interpretation of data, and Almeida CSL and Maia MRG contributed to the initial study design, data collection, analysis, interpretation of data and drafting of the article, Reticena KO contributed to the analysis, data interpretation and writing of the article and Sales CA contributed to the guidelines for the preparation of all the steps of the article and final approval of the version to be published.

\section{References}

1. Sousa ATO, França JRFS, Nóbrega MML, Fernandes MGM, Costa SFG. Palliative care: a conceptual analysis. Online Braz J Nurs [periódico na Internet] 2010; 9(2): [cerca de 8 p.]. Available from: http:// www.objnursing.uff.br/index.php/nursing/ article/view/j.1676-4285. 2010.2947/667

2. Sales CA, D'Artibale EF. O cuidar na terminalidade da vida: Escutando os familiares. Ciênc Cuid Saúde. 2011; 10(4):666-73.

3. Yamaguchi AM, Higa-Taniguchi KT, Andrade L, Carvalho SAP. Assistência domiciliar: uma proposta interdisciplinar. Barueri: Manole; 2009.

4. Fratezi FR, Gutierrez BAO. Cuidador familiar do idoso em cuidados paliativos: o processo de morrer no domicílio. Ciênc Saúde Coletiva. 2011; 16(7):3241-8.

5. Monteiro FF, Oliveira M, Vall J. A importância dos cuidados paliativos na enfermagem. Rev Dor. 2010; 11(3):242-8.

6. Organização Mundial de Saúde (OMS). World cancer report, 2008. Lyon: International Agency for Research on Cancer; 2009.

7. Torres-Mesa LM, Schmidt-Riovalle J, GarciaGarcia I. Conocimiento de la ley y preparación del personal sanitario sobre el proceso asistencial de la muerte. Rev Esc Enferm USP. 2013; 47( 2):46470. 
8. Melo AGC, Caponemo R. Cuidados paliativosabordagem contínua e integral. In: Santos SS. Cuidados paliativos discutindo a vida, a morte e o morrer. São Paulo: Atheneu; 2009. p. 257-67.

9. Oliveira SG, Quintana AM, Budó MLD, Kruse MHL, Garcia RP, Simon BS. Family caregivers coping with terminality during home care. Rev Rene. 2013; 14(3):460-9.

10. Silva MJP, Araújo MP, Firmino F. Enfermagem. In: Oliveira RA, organizador. Cuidado paliativo. São Paulo: Conselho Regional de Medicina do Estado de São Paulo; 2008. p. 61-3.

11. Minayo MCS, organizadora. Pesquisa social: teoria, método e criatividade. Petropolis: Vozes; 2012.

12. Boemer MR. About palliative care. Rev Esc Enferm USP. 2009; 43(3):500-1.

13. Wegner W, Pedro ENR. Os múltiplos papéis sociais de mulheres cuidadoras-leigas de crianças hospitalizadas. Rev Gaúcha Enferm. 2010; 31(2):335-42.

14. Silva MM, Moreira MC, Leite JL, Erdmann AL. Analysis of nursing care and the participation of families in palliative care in cancer. Texto Contexto Enferm. 2012; 21(3):658-66.

15. Valente SH, Teixeira MB. Phenomenological study about the nurse's home care for families of terminally ill patients. Rev Esc Enferm USP. 2009; 43(3):655-61.

16. Salci MA, Sales CA, Marcon SS. Sentimentos de mulheres ao receber o diagnóstico de câncer. Rev Enferm UERJ. 2009; 17(1):46-51.

17. Becker AL. Ethical considerations of teaching spirituality in the academy. Nurs Ethics [serial online]. 2009; 16(6):697-706. Available from: http://nej.sagepub.com/content/16/6/697.short

18. Amendola F, Oliveira MA, Alvarenga MR. Influence of social support on the quality of life of family caregivers while caring for people with dependence. Rev Esc Enferm USP. 2011; 45(4):884-9.

19. Andrade GN, Panza AR, Vargens OM. As redes de apoio no enfrentamento do câncer de mama: uma abordagem compreensiva. Ciênc Cuid Saúde. 2011; 10(1):82-8.

20. Rodrigues JSM, Ferreira NMLA. Structure and functionality of the social support network for adults with cancer. Acta Paul Enferm. 2012; 25(5):781-7.

21. Mufato LF, Araújo LFS, Bellato R, Nepomuceno MAS. Mediation in care networking for patients and families experiencing colorectal cancer. Texto Contexto Enferm. 2013; 22(2):407-15. 